\title{
Relative Effects of Demethylation-Inhibiting Fungicides on Late Leaf Spot of Peanut
}

\begin{abstract}
A. K. Culbreath, ${ }^{\dagger}$ Department of Plant Pathology, University of Georgia, Coastal Plain Experiment Station, Tifton, 31793-5766; A. J. Gevens, Department of Plant Pathology, University of Wisconsin, Madison, 53706; and K. L. Stevenson, Department of Plant Pathology, University of Georgia, Coastal Plain Experiment Station, Tifton, 31793-5766
\end{abstract}

Accepted for publication 17 December 2017.

\section{Abstract}

Field experiments were conducted in Tifton, GA, in 2007, 2008, and 2016, and in Plains, GA, in 2016 to examine the effects of various demethylation-inhibiting (DMI) fungicides on late leaf spot (Nothopassalora personata) of peanut (Arachis hypogaea) and to determine the relative efficacy of the DMI fungicides compared with tebuconazole and the protectant fungicide chlorothalonil. In all trials, leaf spot control provided by tebuconazole, metconazole, tetraconazole, propiconazole, and flutriafol was inferior to that provided by chlorothalonil. However, prothioconazole was superior to chlorothalonil for control of leaf spot in all trials. These results indicated that reduced efficacy of tebuconazole for control of late leaf spot coincides with similar reductions in control with most other available DMI fungicides. However, superior leaf spot control obtained with prothioconazole relative to the other DMI fungicides and chlorothalonil implies that efficacy of tebuconazole is not indicative of the performance of all other DMI fungicides on this disease.
Systemic demethylation inhibitor (DMI) fungicides are used widely for management of leaf spot diseases of peanut (Arachis hypogaea L.), caused by Cercospora arachidicola (Hori) and Nothopassalora personata (Berk. \& M. A. Curtis) S.A. Khan \& M. Kamal (formerly Cercosporidium personatum [Berk. \& M. A. Curtis] Deighton); southern stem rot, caused by Sclerotium rolfsii (Sacc.); and Rhizoctonia limb rot, caused by Rhizoctonia solani (Kühn). The DMI fungicide tebuconazole is one of the most widely used fungicides in peanut in the United States. The labeled typical use pattern in the southeastern United States had been four consecutive applications of tebuconazole at $225 \mathrm{~g}$ of active ingredient (a.i.) per hectare per application following one or two applications of chlorothalonil at $1.26 \mathrm{~kg}$ a.i./ha, a mixture of chlorothalonil plus propiconazole, or pyraclostrobin. The subsequent consecutive applications of tebuconazole were initiated approximately 60 days after planting (DAP) (Culbreath et al. 2006).

Tebuconazole has been labeled for use on peanut in the United States since 1994 and remains one of the predominant fungicides used on peanut in Georgia, Alabama, and Florida. Relative performance of tebuconazole and chlorothalonil for leaf spot control changed drastically within 10 years of the registration of tebuconazole, with tebuconazole frequently less effective than chlorothalonil for leaf spot control (Chapin and Thomas 2006; Culbreath et al. 2005). An increase in the frequency of isolates with reduced sensitivity to tebuconazole in populations of the peanut leaf spot pathogens has been reported (Stevenson and Culbreath 2006).

Field resistance to DMI fungicides has been reported in a number of other plant pathogens, and cross-resistance among members of

${ }^{\dagger}$ Corresponding author: A. K. Culbreath; E-mail: spotwilt@uga.edu

Funding: This research was funded in part by the National Peanut Board, the Georgia Agricultural Commodity Commission for Peanuts, and Georgia Foundation Seed. We also acknowledge the U.S. Department of Agriculture-National Institute of Food and Agriculture, Hatch Project GEO-00691.

(C) 2018 The American Phytopathological Society the DMI group is common (Cools et al. 2013; Hsiang et al. 1997; Karaoglanidis and Thanassoulopoulos 2003; Köller 1988; Köller et al. 1997). However, owing to different resistance mechanisms or differences in intrinsic activity of the fungicide, resistance in a plant pathogen to one DMI compound may not necessarily predict crossresistance to another compound in the group (Fraaije et al. 2007; Leroux et al. 2007; Villani et al. 2015). This study was conducted to determine the relative field performance of several DMI fungicides, with particular emphasis on comparison with tebuconazole and chlorothalonil treatments in locations where performance of tebuconazole has declined.

\section{Relative Fungicide Efficacy for Leaf Spot Control}

Peanuts were planted in fields of Tifton loamy sand at the Coastal Plain Experiment Station, Lang Farm (latitude 31.516; longitude -83.549), Tifton, GA, on May 25, 2007, May 27, 2008, and May 24, 2016, and in a field of Greenville clayey loam at the Southwest Branch Station (latitude 32.039; longitude -84.371), Plains, GA, on May 23, 2016. The fields used in 2007 and 2016 had been planted to cotton (Gossypium hirsutum L.) the previous year but had been planted to peanut two years prior, and the field used in 2008 had been planted to peanut the previous year. Conventional tillage was used in all experiments. Cultivars used were Carver (Gorbet 2006) at Tifton in 2007, Florida-07 (Gorbet and Tillman 2009) in 2008, and Georgia-13M (Branch 2014) at both locations in 2016. In 2007 and 2008, plots received aldicarb (Temik 15G, Bayer CropScience, Research Triangle Park, NC) at $1.12 \mathrm{~kg}$ a.i./ha infurrow at planting for control of feeding injury by tobacco thrips (Frankliniella fusca [Hinds]). No insecticide was applied for control of thrips at either location in 2016. Plot width was $1.83 \mathrm{~m}$, with row spacing a uniform $0.91 \mathrm{~m}$ on the $1.83-\mathrm{m}$ bed for all trials. Plot length was $7.9 \mathrm{~m}$ in 2007, $8.2 \mathrm{~m}$ in 2008, and $8.5 \mathrm{~m}$ in both locations 2016 . Plots were separated by two nonsprayed border rows, and blocks were separated by $2.4-\mathrm{m}$ fallow alleys. A randomized complete block experimental design with four replications was used in all 
trials. In 2007 and 2008, 10 treatments consisted of (i) a nontreated control, (ii) $1.26 \mathrm{~kg}$ a.i./ha of chlorothalonil (Bravo WeatherStik 720 F, Syngenta, Greensboro, NC), (iii) $0.23 \mathrm{~kg}$ a.i./ha of tebuconazole (Folicur 3.6 F, Bayer CropScience), (iv) $0.040 \mathrm{~kg}$ a.i./ha of cyproconazole (Alto $100 \mathrm{SL}$, Syngenta, Greensboro, NC), (v) $0.062 \mathrm{~kg}$ a.i./ha of cyproconazole (Alto $100 \mathrm{SL}$ ), (vi) $0.20 \mathrm{~kg}$ a.i./ha of prothioconazole (Proline $480 \mathrm{SC}$, Bayer CropScience), (vii) $0.065 \mathrm{~kg}$ a.i./ha of tetraconazole (Eminent 125 SL, Sipcam Agro USA, Roswell, GA), (viii) $0.226 \mathrm{~kg}$ a.i./ha of flusilazole (Punch $3.3 \mathrm{SC}$, Dupont Crop Protection, Wilmington, DE), (ix) $0.13 \mathrm{~kg}$ a.i./ha of propiconazole (Tilt $3.6 \mathrm{EC}$, Syngenta), and (x) $0.14 \mathrm{~kg}$ a.i./ha of metconazole (Quash 50 WG, Valent, Walnut Creek, CA) (Table 1). In 2016, propiconazole was omitted and $0.13 \mathrm{~kg}$ a.i./ha of flutriafol (TopGuard 1.04 DC, FMC Corporation, Philadelphia, PA) was added (Table 2). In 2016, the Folicur 3.6 formulation of tebuconazole was no longer available, so the tebuconazole treatment was applied as Orius 3.6 (Adama, Raleigh, NC).

All fungicides were applied for the full season at approximately 14-day intervals, with a total of seven applications in 2007 and six applications in 2008 and 2016. Fungicide applications were made $38,52,61,74,89,105$, and 122 DAP in 2007; 43, 57, 71, 85, 99, and 113 DAP in 2008; and 49, 69, 80, 93, 107, and $121 \mathrm{DAP}$ at Tifton and 53, 71, 81, 97, 111, and 125 DAP at Plains in 2016. Fungicide applications were made using a multiple-boom tractormounted $\mathrm{CO}_{2}$-propellant sprayer. Each boom was equipped with three spray nozzles per row. Nozzle types were D3-23 hollow-cone in 2007 and Hypro TR80-03 flat fan in 2008 and 2016. Fungicides were applied in 187 liters/ha of water at a pressure of $310 \mathrm{kPa}$. With the exception of fungicide treatments, plots were maintained using University of Georgia Extension Service recommendations.

Leaf spot severity was assessed visually for entire plots by use of the ordinal Florida 1-10 scale where $1=$ no leaf spot and $10=$ plants completely defoliated and killed by leaf spot (Chiteka et al. 1988). Leaf spot severity was assessed $96,111,133$, and 139 DAP in 2007; 80, 107, 122, and 147 DAP in 2008; 112, 119, 133, and 139 DAP in 2016 at Tifton; and 111, 125, and 139 DAP in 2016 at
Plains. Areas under the disease progress curves (AUDPCs) were calculated using Florida scale values as described by Shaner and Finney (1977). Because the time for monitoring epidemics differed among the trials, AUDPC was standardized by dividing by the duration in days across which evaluations were made (Madden et al. 2007).

\section{Data Analysis}

Because final leaf spot severity was assessed using an ordinal scale that does not represent a continuous scale of measurement, this variable was analyzed nonparametrically based on ranks (Shah and Madden 2004). The trials in 2007 and 2008 were analyzed across years, and the trials in 2016 were analyzed across locations. Relative treatment effects and their respective $95 \%$ confidence intervals were calculated using the LD_CI macro for SAS (Brunner et al. 2002; Shah and Madden 2004) and were used to discern differences among the fungicide treatments. Relative treatment effect $\left(\hat{p}_{i}\right)$ was estimated from the mean ranks according to the following equation:

$$
\hat{p}_{i}=\frac{1}{N}\left(\bar{R}_{i} \cdot-\frac{1}{2}\right)
$$

where $\bar{R}_{i}$. is the mean rank for the treatment among all observations $(N)$. Relative treatment effects have a range of 0 to 1.0. Two relative treatment effects were considered different $(P \leq 0.05)$ if they each lay outside the confidence interval of the other.

For all variables except final leaf spot ratings, data were analyzed across years for the 2007 and 2008 trials and across locations for the 2016 trials using PROC GLIMMIX with ddfm = satterth option on the model statement (SAS version 9.4; SAS Institute, Cary, NC). In all trials, fungicide treatments were considered fixed effects. For trials conducted in 2007 and 2008, year, replication(year), and yeartreatment were considered random effects. Similarly, for trials conducted in 2016, location, replication(location), and locationtreatment were considered random effects. Significance of differences

\begin{tabular}{|c|c|c|c|c|c|c|c|}
\hline \multicolumn{8}{|c|}{$\begin{array}{l}\text { TABLE } 1 \\
\text { Mean rank }\left(\overline{\boldsymbol{R}}_{i}\right) \text {, and estimated relative treatment effects }\left(\hat{p}_{i}\right) \text { with } 95 \% \text { confidence intervals (Cls) for final leaf spot } \\
\text { severity, standardized area under the disease progress curve (stAUDPC) for late leaf spot, and peanut pod yield for different } \\
\text { fungicide treatments, Tifton, GA, } 2007 \text { to } 2008\end{array}$} \\
\hline Fungicide & Rate (kg a.i./ha) & Medianw $^{w}$ & $\overline{\boldsymbol{R}}_{\boldsymbol{i}}$ & $\hat{\boldsymbol{p}}_{i}^{\mathbf{X}}$ & $95 \% \mathrm{Cl}^{\mathrm{y}}$ for $\hat{p}_{i}$ & stAUDPCw & Yieldw (kg/ha) \\
\hline Nontreated & $\ldots$ & 9.8 & 67.8 & 0.934 & $0.866,0.943$ & $5.4 \mathrm{a}^{\mathrm{z}}$ & $3,600 \mathrm{e}^{\mathrm{z}}$ \\
\hline Propiconazole & 0.13 & 7.5 & 42.0 & 0.576 & $0.344,0.437$ & $3.7 \mathrm{~b}$ & $5,661 \mathrm{~cd}$ \\
\hline Cyproconazole & 0.040 & 7.0 & 39.1 & 0.536 & $0.425,0.643$ & $3.6 \mathrm{~b}$ & $5,769 \mathrm{~cd}$ \\
\hline Metconazole & 0.14 & 7.3 & 40.3 & 0.555 & $0.442,0.660$ & $3.7 \mathrm{~b}$ & $6,130 \mathrm{bc}$ \\
\hline Chlorothalonil & 1.26 & 5.5 & 18.0 & 0.243 & $0.206,0.287$ & $2.7 \mathrm{c}$ & $6,234 \mathrm{bc}$ \\
\hline Flusilazole & 0.226 & 4.9 & 17.9 & 0.241 & $0.163,0.355$ & $2.4 \mathrm{c}$ & $6,675 a b$ \\
\hline
\end{tabular}

${ }^{\mathrm{v}}$ Final leaf spot was assessed visually shortly before plot inversion with the ordinal Florida 1 to 10 scale where $1=$ no disease and $10=$ plants completely defoliated and killed by leaf spot (Chiteka et al. 1988).

${ }^{\text {w }}$ Median and mean values presented are from analysis across years.

${ }^{\mathrm{x}}$ Estimated relative treatment effects $\left(\hat{p}_{i}\right)\left(0<\hat{p}_{i}<1.0\right)$ and the respective 95\% CIs were calculated by the method of Shah and Madden $(2004)$ from a nonparametric ranks-based analysis using the LD_CI SAS macro.

${ }^{\mathrm{y}}$ Lower and upper limits for the CI $(95 \%)$ for the respective relative treatment effect. Two treatments are considered different $(P \leq 0.05)$ for the relative treatment effect for that mean if they each lie outside the CI of the other.

${ }^{\mathrm{z}}$ Means within the same column with the same letter are not different $(P>0.05)$ as determined using lsmeans/pdiff lines option for PROC GLIMMIX, SAS version 9.4 
TABLE 2

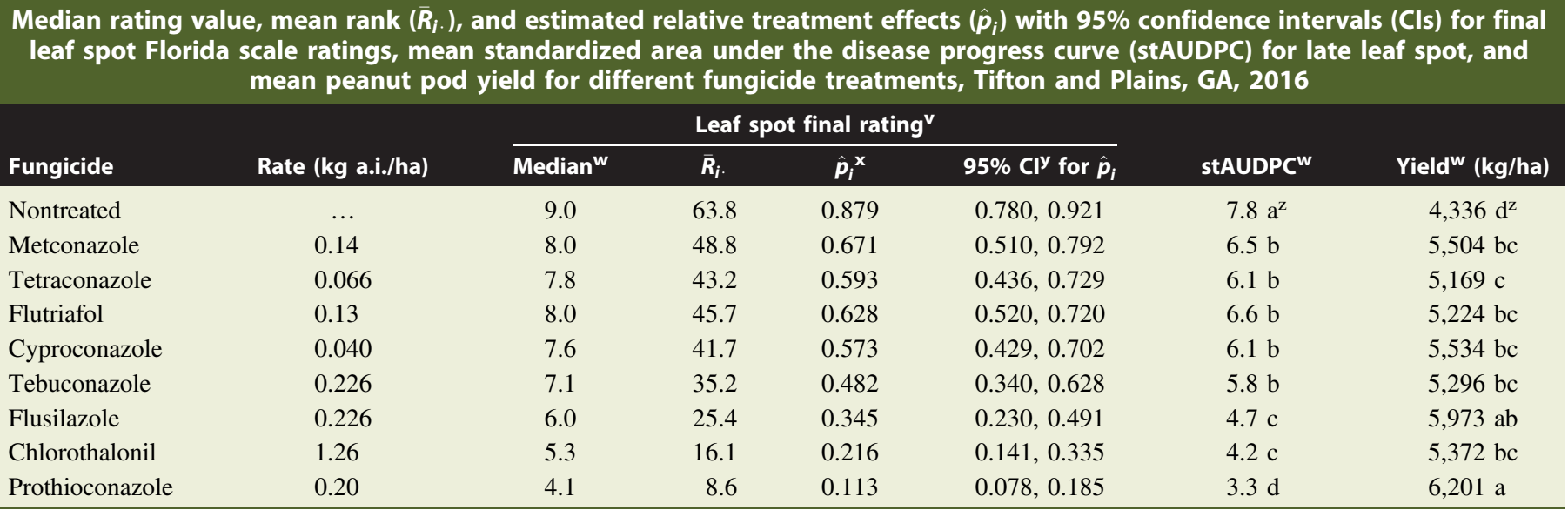

${ }^{\mathrm{v}}$ Final leaf spot severity was assessed visually shortly before plot inversion assessed with the ordinal Florida 1 to 10 scale where $1=$ no disease and $10=$ plants completely defoliated and killed by leaf spot (Chiteka et al. 1988).

${ }^{\mathrm{w}}$ Median and mean values presented are from analysis across locations in 2016.

${ }^{\mathrm{x}}$ Estimated relative treatment effects $\left(\hat{p}_{i}\right)\left(0<\hat{p}_{i}<1.0\right)$ and the respective 95\% CIs were calculated by the method of Shah and Madden $(2004)$ from a nonparametric ranks-based analysis using the LD_CI SAS macro.

${ }^{\mathrm{y}}$ Lower and upper limits for the CI $(95 \%)$ for the respective relative treatment effect. Two treatments are considered different $(P \leq 0.05)$ for the relative treatment effect for that mean if they each lie outside the CI of the other.

${ }^{\mathrm{z}}$ Means within the same column with the same letter are not different $(P>0.05)$ as determined using lsmeans/pdiff lines option for PROC GLIMMIX, SAS version 9.4 .

between individual pairs of means was determined using the lsmeans/ pdiff lines option for PROC GLIMMIX. All subsequent reference to significant effects of treatments or differences among means indicates significance at $P \leq 0.05$ unless otherwise stated.

\section{Fungicide Effects on Leaf Spot and Peanut Yield}

Late leaf spot was the predominant foliar disease ( $>95 \%$ of the foliar disease present) late in the season in all experiments. Epidemics began later in the season in 2007 than in 2008 or 2016, but they were severe by time of harvest in all years. Plants in the nontreated control were almost completely defoliated by leaf spot in all years. Final leaf spot ratings and standardized AUDPC values for all treatments were lower than for the nontreated control in both sets of experiments (Tables 1 and 2). Across 2007 and 2008, final leaf spot ratings and standardized AUDPC values did not differ among treatments of tebuconazole, tetraconazole, propiconazole, metconazole, or cyproconazole (Table 1). Disease ratings and AUDPC values in all of those treatments were higher than those of the chlorothalonil standard. Final leaf spot ratings and AUDPC values were similar for flusilazole and chlorothalonil treatments. Final leaf spot ratings were lower in the prothioconazole treatment than in any other treatment, but standardized AUDPC values for prothioconazole were similar to those of chlorothalonil (Table 1). In 2016, final leaf spot ratings were higher for metconazole than for tebuconazole, but there were no differences among tebuconazole, tetraconazole, cyproconazole, or flutriafol (Table 2). Final leaf spot ratings in all of those treatments and the flusilazole treatment were higher than those of the chlorothalonil standard (Table 2). Standardized AUDPC values did not differ among metconazole, tebuconazole, tetraconazole, cyproconazole, or flutriafol and were higher for all of those treatments than the chlorothalonil treatment (Table 2). Standardized AUDPC values were similar for flusilazole and chlorothalonil treatments. Final leaf spot ratings and standardized AUDPC values were lower in the prothioconazole treatment than in any other treatment (Table 2).

Across 2007 and 2008, all treatments resulted in higher yields than the nontreated control (Table 1). Yield for the prothioconazole treatment was higher than for all other treatments except the flusilazole treatment (Table 1). Metconazole and chlorothalonil treatments had yields greater than that of tetraconazole, but yields did not differ among any of the remaining fungicide treatments (Table 1). In 2016, all treatments resulted in higher yields than the nontreated control. Yield for the prothioconazole treatment was higher than for all other treatments except the flusilazole treatment (Table 2). There were no differences in yield among the other fungicide treatments (Table 2).

\section{Implications for Leaf Spot Management}

Results of this study corroborate previous reports that tebuconazole is less effective than chlorothalonil for leaf spot control (Culbreath et al. 2008) and are consistent with reports that local populations of $C$. personatum are less sensitive to tebuconazole than in the past (Culbreath et al. 2005; Stevenson and Culbreath 2006; Stevenson et al. 1999). By harvest time in all years, plants treated with tebuconazole were heavily defoliated. Results indicated that treatment with tetraconazole, metconazole, propiconazole, cyproconazole, and flutriafol provided a level of leaf spot control similar to that of tebuconazole.

In the earlier set of trials, flusilazole provided leaf spot control similar to that of chlorothalonil and superior to tebuconazole. Although in 2016, flusilazole provided leaf spot control that was better than that of tebuconazole, it was inferior to chlorothalonil for leaf spot control. Flusilazole has not been labeled for use on peanut in the United States. These results indicate that performance of this fungicide relative to chlorothalonil has changed since 2008 even with no commercial use, and they suggest cross-resistance in $N$. personata populations to tebuconazole and flusilazole. The rate of flusilazole used in this study was higher than the rates used for leaf spot control in Argentina, where it is labeled for use on peanut (Pedelini 1998). Although cyproconazole was first labeled for use on peanut in 2013, it was tested extensively in the early 1990s (Culbreath et al. 1995). The cyproconazole treatment was not as effective as would have been expected based on previous rate response results for late leaf spot in field experiments in 1990 to 
1991 (Culbreath et al. 1995) and performance of $0.034 \mathrm{~kg}$ a.i./ha of cyproconazole compared with chlorothalonil in field trials in 1992 to 1993 (Culbreath et al. 1995). Although metconazole and tetraconazole have been available for commercial use, neither has been used as extensively as tebuconazole. However, in this study, neither provided better control of late leaf spot than tebuconazole.

In contrast to all other DMI fungicides included in this study, prothioconazole provided control of late leaf spot that was superior to that of chlorothalonil in all trials. This is consistent with a previous report of $0.20 \mathrm{~kg}$ a.i./ha of prothioconazole providing leaf spot control superior to that of chlorothalonil in four of six trials conducted in Tifton and Plains, GA, in 2001 and 2003 (Culbreath et al. 2008). However, during those 3 years, leaf spot control was similar for the tebuconazole and chlorothalonil treatments in five of the six trials, and in the one trial in which tebuconazole was inferior to chlorothalonil, there was little defoliation (Culbreath et al. 2008). In this study, $0.20 \mathrm{~kg}$ a.i./ha of prothioconazole was effective in fields in which late leaf spot was not controlled by $0.225 \mathrm{~kg}$ a.i./ha of tebuconazole or several other DMI fungicides. Although prothioconazole had been used in small experimental plots at the same location since 2001, exposure of leaf spot pathogens to that fungicide prior to the 2007 and 2008 experiments had been limited. However, prothioconazole was labeled for use on peanut in the United States in 2007, and a combination product of prothioconazole and tebuconazole (Provost 433 SC, Bayer CropScience, Research Triangle Park, NC) has been used extensively in commercial peanut production since then. Nonetheless, there was no indication of change in the relative efficacy of prothioconazole or chlorothalonil from 2007 to 2016.

Full-season use of any of these DMI fungicides would be neither allowable based on label restrictions nor advisable based on suggested resistance management strategies for this class of fungicides (Brent 1995). Fungicide effects on yield observed with full-season consecutive applications should not be assumed to be predictors of yield when fewer applications are made in integrated regimes with other fungicides. Therefore, implications of the yield results of this study are limited primarily to the suggestion that less-effective leaf spot control can result in reduced yield. The primary purpose of full-season use of these fungicides was to compare efficacies on leaf spot without potential confounding effects of other fungicides used in alternation or mixtures.

\section{Conclusions}

Results from this study suggest that the reduced efficacy of tebuconazole for control of late leaf spot coincides with similar reductions in control with all but one of the other DMI fungicides typically used in peanut in the southeastern United States. However, superior leaf spot control obtained with prothioconazole relative to the other DMI fungicides and chlorothalonil implies that efficacy of tebuconazole is not indicative of the performance of all DMI fungicides on this disease.

\section{Acknowledgments}

The authors thank Mike Heath, Ron Hooks, Stan Jones, Matthew Wiggins, Kyle Parris, Neal Roberson, and Harvey Kendrick for their help in this project.

\section{Literature Cited}

Branch, W. D. 2014. Registration of 'Georgia-13M' peanut. J. Plant Regist. 8: 253-256.
Brent, K. J. 1995. Fungicide resistance in crop pathogens: How can it be managed? Fungicide Resistance Action Committee Monograph No. 1, 2nd Ed. Global Crop Protection Federation, Brussels.

Brunner, E., Domhof, S., and Langer, F. 2002. Nonparametric Analysis of Longitudinal Data in Factorial Experiments. Wiley, New York.

Chapin, J. W., and Thomas, J. S. 2006. Late leaf spot resistance to tebuconazole (Folicur): Responding to control failures, and implications for peanut disease management programs in South Carolina. Proc. Am. Peanut Res. Ed. Soc. 38: 54 (abstr.).

Chiteka, Z. A., Gorbet, D. W., Shokes, F. M., Kucharek, T. A., and Knauft, D. A. 1988. Components of resistance to late leafspot in peanut. I. Levels and variability-Implications for selection. Peanut Sci. 15:25-30.

Cools, H. J., Hawkins, N. J., and Fraaije, B. A. 2013. Constraints on the evolution of azole resistance in plant pathogenic fungi. Plant Pathol. 62: $36-42$.

Culbreath, A. K., Brenneman, T. B., Bondari, K., Reynolds, K. L., and McLean, H. S. 1995. Late leaf spot, southern stem rot, and peanut yield responses to rates of cyproconazole and chlorothalonil applied alone and in combination. Plant Dis. 79:1121-1125.

Culbreath, A. K., Brenneman, T. B., Kemerait, R. C., Jr., and Stevenson, K. L. 2005. Relative performance of tebuconazole and chlorothalonil for control of peanut leaf spot from 1994 through 2004. Proc. Am. Peanut Res. Ed. Soc. 37: 54-55 (abstr.).

Culbreath, A. K., Kemerait, R. C., Jr., and Brenneman, T. B. 2006. Management of early leaf spot of peanut as affected by fungicide and date of spray program initiation. Online publication. Plant Health Prog. doi.org/10.1094/PHP-20060214-01-RS

Culbreath, A. K., Kemerait, R. C., and Brenneman, T. B. 2008. Management of leaf spot diseases of peanut with prothioconazole applied alone or in combination with tebuconazole or trifloxystrobin. Peanut Sci. 35:149-158.

Fraaije, B. A., Cools, H. J., Kim, S. H., Motteram, J., Clark, W. S., and Lucas, J. A. 2007. A novel substitution I381V in the sterol $14 \alpha$-demethylase (CYP51) of Mycosphaerella graminicola is differentially selected by azole fungicides. Mol. Plant Pathol. 8:245-254.

Gorbet, D. W. 2006. Registration of 'Carver' peanut. Crop Sci. 46:2713-2714.

Gorbet, D. W., and Tillman, B. L. 2009. Registration of 'Florida-07' peanut. J. Plant Regist. 3:14-18.

Hsiang, T., Yang, L., and Barton, W. 1997. Baseline sensitivity and crossresistance to demethylation-inhibiting fungicides in Ontario isolates of Sclerotinia homoeocarpa. Eur. J. Plant Pathol. 103:409-416.

Karaoglanidis, G. S., and Thanassoulopoulos, C. C. 2003. Cross-resistance patterns among sterol biosynthesis inhibiting fungicides (SBIs) in Cercospora beticola. Eur. J. Plant Pathol. 109:929-934.

Köller, W. 1988. Sterol demethylation inhibitors: Mechanism of action and resistance. Pages 79-88 in: Fungicide Resistance in North America. C. J. Delp, ed. American Phytopathological Society, St. Paul, MN.

Köller, W., Wilcox, W. F., Barnard, J., Jones, A. L., and Braun, P. G. 1997. Detection and quantification of resistance of Venturia inaequalis populations to sterol demethylation inhibitors. Phytopathology 87:184-190.

Leroux, P., Albertini, C., Gautier, A., Gredt, M., and Walker, A.-S. 2007. Mutations in the CYP51 gene correlated with changes in sensitivity to sterol $14 \alpha$-demethylation inhibitors in field isolates of Mycosphaerella graminicola. Pest Manag. Sci. 63:688-698.

Madden, L. V., Hughes, G., and van den Bosch, F. 2007. The Study of Plant Disease Epidemics. American Phytopathological Society, St. Paul, MN.

Pedelini, R. 1998. Control quimico de viruela. Pages 35-37 in: Manual del Mani, 3rd Ed. R. Pedelini and C. Casini, eds. Instituto Nacional de Technologia Agropecuaria, Manfredi, Cordoba, Argentina.

Shah, D. A., and Madden, L. V. 2004. Nonparametric analysis of ordinal data in designed factorial experiments. Phytopathology 94:33-43.

Shaner, G., and Finney, R. E. 1977. The effect of nitrogen fertilization on the expression of slow-mildewing resistance in Knox wheat. Phytopathology 67:1051-1056.

Stevenson, K. L., and Culbreath, A. K. 2006. Evidence for reduced sensitivity to tebuconazole in leaf spot pathogens. Proc. Am. Peanut Res. Ed. Soc. 38:62 (abstr.).

Stevenson, K. L., Padgett, G. B., and Culbreath, A. K. 1999. Sensitivity of early and late peanut leaf spot pathogens to DMI fungicides. Proc. Am. Peanut Res. Ed. Soc. 31:23 (abstr.).

Villani, S. M., Biggs, A. R., Cooley, D. R., Raes, J. J., and Cox, K. D. 2015. Prevalence of myclobutanil resistance and difenoconazole insensitivity in populations of Venturia inaequalis. Plant Dis. 99:1526-1536. 